\title{
Hormonal contraception as a risk factor for obesity
}

\author{
Sri Sugiharti ${ }^{*}$, Hamam Hadi”, Madarina Julia ${ }^{\S}$
}

\begin{abstract}
Abstrak
Kontrasepsi hormonal berhubungan dengan perubahan dalam metabolisme beberapa zat gizi yang dapat menyebabkan terjadinya peningkatan berat badan. Penelitian ini bertujuan untuk menguji risiko obesitas pada pemakai kontrasepsi hormonal di Kabupaten Kulon Progo, Jogjakarta. Rancangan penelitian potong lintang digunakan untuk menentukan prevalensi obesitas pada penderita kontrasepsi. Sampling klusters acak sistematik dengan desa sebagai klusternya, digunakan untuk memilih 647 pemakai kontrasepsi di Kulon progo. Sebagai kasus didapat 102 pemakai yang 'obese' dan 102 orang sebagai kontrol, sebelumnya dilakukan kesetaraan untuk umur dan status sosial ekonomi pada kasus dan kontrol. Rancangan kasus kontrol dalam penelitian ini dilakukan untuk mengevaluasi risiko obesitas di antara pemakai kontrasepsi hormonal. Penelitian ini menunjukkan prevalensi obesitas di antara pemakai kontrasepsi di Kulon Progo adalah 15.9\%. Pemakai kontrasepsi hormonal memiliki risiko menjadi obesitas sebesar 9.4 kali (95\% CI: 1.1 - 81.5). Pemakai kombinasi pil terlihat memiliki risiko tertinggi, diikuti oleh pemakai susuk, sedangkan risiko pemakai 'implant' sama dengan pemakai kontrasepsi non hormonal. Risiko obesitas tidak berhubungan dengan asupan energi ataupun keluaran energi. Peningkatan risiko obesitas pada pemakai kontrasepsi hormonal tetap signifikan setelah dilakukan kontrol terhadap usia, paritas, berat badan awal, status sosial ekonomi, asupan energi dan keluaran energi serta obesitas pada orang tuanya. Kami menyimpulkan bahwa risiko obesitas lebih besar pada pemakai kontrasepsi hormonal dibandingkan dengan pemakai kontrasepsi nonhormonal. Pemakai kombinasi pil memiliki risiko tertinggi. (Med J Indones 2005; 14: 163-8)
\end{abstract}

\begin{abstract}
Hormonal contraception is related to change in the metabolism of some nutrients that may lead to an increase in body weight. The aims of this study is to assess the risk of obesity in hormonal contraceptive users in the District of Kulon Progo, Jogjakarta, Indonesia. A cross sectional study was used to determine the prevalence of obesity among users of contraception. A systematic cluster random sampling, using villages as clusters, was used to choose 647 users of contraception in Kulon Progo. A hundred and two obese cases and 102 control, matched-for-age and socioeconomic status, controls were included in the case control study used to evaluate the risk of obesity among users of hormonal contraception. The prevalence of obesity among users of contraception in Kulon Progo was 15.9\%. Users of hormonal contraception has a increased risk for obesity, OR: 9.4 (95\% CI: 1.1 - 81.5). Users of combination pills faced the highest risk, followed by users of injected progesterone depot, while the risk in implant users was the same as that in users of non-hormonal contraception. The risk of obesity was significantly higher after 7 years of hormonal contraception use. The risk of obesity was neither related to energy intake nor expenditure. The increased risk of obesity in users of hormonal contraception was still significant after controlling for age, parity, initial weight, socioeconomic status, energy intake and expenditure, and parental obesity. We conclude that the risk of obesity is higher in users of hormonal contraception compared to the non-hormonal ones. Users of combination pills face the highest risk of obesity. (Med J Indones 2005; 14: 163-8)
\end{abstract}

Keywords: hormonal contraception, family planning, obesity, case control study

Family planning, as one of the Indonesian Government's program for development, strives to promote welfare by creating small, happy and prosperous families. One of the main efforts in Family Planning is birth arrangement, i.e. having 'ideal' number of children, ideal birth spacing between children and ideal age to give birth. ${ }^{1,2}$ Most

\footnotetext{
*Yogyakarta National Family Planning Board Office (BKKBN)

${ }^{\#}$ Department of Public Health, Faculty of Medicine, University of Gadjah Mada, Yogyakarta, Indonesia

${ }^{\S}$ Department of Pediatric, Faculty of Medicine, University of Gadjah Mada, Yogyakarta, Indonesia
}

of the success of birth arrangement is related to the use of contraception. There are many reasons for choosing one mode of contraception e.g. its effectiveness, its convenience or its minimal side effects. ${ }^{3,4,5}$

In the last five years there are an increase in the use of hormonal contraception in the District of Kulon Progo, Jogjakarta, Indonesia. ${ }^{6}$ Hormonal contraception is known to be related to weight gain. ${ }^{5,7}$ Progesterone in a steroid contraceptive drug influences the metabolism of nutrients, i.e. by promoting anabolism and by increasing appetite. Estrogen leads to the deposition of fat in the 
subcutaneous tissue and causes increased absorption of salt and water. The weight gain occurs gradually. ${ }^{8,9}$

Obesity is closely related to some diseases such as hypertension, coronary heart diseases, diabetes mellitus and respiratory diseases. Epidemiological studies have shown the increased risk of mortality and morbidity to such diseases in people with obesity. ${ }^{10}$

The study is intended to assess the risk of obesity in hormonal contraceptive users in the District of Kulon Progo, Jogjakarta, Indonesia.

\section{METHODS}

This is a case control study, using obese contraceptive users as cases and non-obese contraceptive users as controls. A preliminary survey was done to find the prevalence of obesity in contraceptive users in the district and was carried out before the main study.

The study was performed in August - October 2001 in Kulon Progo Jogjakarta. Study population were female contraceptive users living in the district during the study period. Subjects were excluded if they still gave breastfeeding or had chronic diseases such as tuberculosis and malaria.

The study was approved by the ethical committee of Gadjah Mada University, Jogjakarta, Indonesia. Informed consents were obtained from every eligible subject.

\section{Sampling procedures}

For a cross sectional survey intended to find the prevalence of obesity in female contraceptive users, $10 \%$ of villages were randomly chosen from 88 villages in the district. All female contraceptive users in 9 villages underwent anthropometrics measurements. Interviewers in this study are fieldworkers family planning who had education background in health science. Interview was done in subjects' houses. There were 103 obese subjects, i.e. BMI (body mass index) of more than 25 .

Our of those 103 obese subjects, 102 became cases. One obese contraceptive user moved out from the village before the second part of the study. For those 102 cases, 102 non-obese female contraceptive users i.e. BMI of 18.5 to 24.9 , matched for age, families' socioeconomic status and village, were chosen as controls. Matched for age is two group (age $\leq 35$ year, $>35$ year).
Families socioeconomic status is two group. One group is preprosperous and stage 1 prosperous, another is stage II, III and III plus. Preprosperous family : families that are unable to fulfill even the minimum quantity of their own basic needs, such of food, clothing, housing and health. Prosperous family stage I; families that are unable to fulfill their minimum basic needs, but are still unable to meet their sociopsychological needs, such as education, family planning, communication within family, interaction with their immediate social environment, and their needs for transportation services. Prosperous family stage II: families that are able to meet their basic needs and theirs socio-psychological needs, but are still unable to fulfill their development needs, such as the need to save and to obtain information. Prosperous family stage III: families that are capable of fulfilling their basic, socio-psycological and development needs, but are still unable to give sufficient contribution to societal life, in terms of monetary, material and in their active participation social activities. Prosperous family stage III plus: families that are capable of fulfilling all their needs, i.e. basic, socio-psychologycal, developmental and social participation.

\section{Data collection}

Data were collected using questionnaire forms and anthropometrics measurements. Training of interviewers and testing of questionnaires were performed before the actual data collection. All interviewers spoke the native languages.

The subject's height was measured with a microtoise to the nearest $0.1 \mathrm{~cm}$, while her weight was measured with a Seca digital scale (Germany) to the nearest 0.1 $\mathrm{kg}$. Due to the tropical weather, light clothing was the custom in the area. Data on weight and height was converted to BMI (body mass index), which is weight (in $\mathrm{kg}$ )/square of height (in $\mathrm{m}$ ). Waist and hip circumferences were measured with non-stretchable tapes to the nearest $0.1 \mathrm{~cm}$. Waist was measured at the level of the navel, while hip was measured at the largest circumference of the hip girdle.

Data on contraceptive utilization included the types of contraception presently used, either hormonal or nonhormonal, and the duration of utilization. The data that respondents might have used hormonal contraceptive sometime in the past was also recorded. Data on her initial body weight before the utilization of the latest contraceptive method was taken from her Family 
Planning member's card. Other data in the questionnaire were age, parity, level of education, occupation, obesity in either parents and socioeconomic status based on family's income and national standard. This national standard of assessing family welfare divided families into 5 levels of welfare based on ability to purchase food, decent clothing and housing, and health services.

Data on food intake were collected by a 24-hour dietary recall. The dietary recall was performed on three non-consecutive recall days, one of them had to be on Sundays or holidays. Data on energy expenditure were also collected by a 24-hour activity recall. This activity recall was also performed three times, on the same day of the dietary recall.

Data on food intake were analyzed using Food Processor II Nutrition Analysis System 2400 Foods30 nutrients (Cetapharm/MSD version 3.14, Salem, Oregon, USA), while data on daily energy expenditure were the sum of basal metabolic rate, energy expended for a specific activity per $\mathrm{kg}$ body weight per hour - using list by Guthrie, 1986 - and specific dynamic action (Auliana, 1999). Statistical analysis was $95 \%$ confidence intervals performed using Epiinfo 2000 version $1.0,{ }^{11}$ and stata. ${ }^{12}$

\section{RESULTS}

Survey in 9 villages in the district found 647 contraceptive users, 103 of whom were obese (15.9\%). This preliminary study showed that the village with the highest prevalence of hormonal contraceptive users (62.6\%) had the highest prevalence of obesity (27.9\%).
The reverse was also true, the less the hormonal contraceptive used, the less was the prevalence of obesity.

The hormonal contraceptives used by our respondents were combination pill (oral pill combination of estrogen and progesterone derivates), intramuscularly injected depot of progesterone derivate and subcutaneous implantation of low-dose levonorgestrel or etonogestrel (implant). The non-hormonal contraceptives used were IUD (intra uterine devices) and tubectomy.

The hormonal contraceptive users had higher risk of being obese compared to the non-hormonal contraceptive users. The risk was highest for users of combination pill, followed by users of injected progesterone depot. Users of implant had no additional risk of obesity compared to the non-hormonal contraceptive users. The risk was still significant after controlling for age, parity, initial body weight, socioeconomic status, education, occupation, daily intake of energy and energy expenditure (see Table 1, 3 and 5).

There was no difference in the duration of contraceptive utilization between the obese group and the control group, but they had significantly different duration in using hormonal contraception (Table 2). This difference was still significant after adjusment of other variables in the multivariate model (Table 5) was done. A stratified analysis showed that utilization of hormonal contraception for more than seven years related to significantly higher risk of obesity (Table 4).

Obese parents tend to have obese daughter (Table 1 and 5). Hormonal or non-hormonal contraception did not show any significant effect on energy intake nor energy expenditure (Table 6).

Table 1. Univariate analysis of risk factors of obesity in users of contraception (for categorical variables)

\begin{tabular}{|c|c|c|c|c|c|}
\hline Variable & $\begin{array}{c}\text { Obese } \\
\mathrm{n}=102\end{array}$ & $\begin{array}{c}\text { Non-obese } \\
n=102\end{array}$ & $\begin{array}{l}\text { Odds } \\
\text { Ratio }\end{array}$ & $95 \% \mathrm{CI}$ & $\mathrm{p}$ \\
\hline \multicolumn{6}{|l|}{ Methods of contraception } \\
\hline Hormonal & 64 & 45 & 2.05 & $1.13-3.73$ & 0.010 \\
\hline Non hormonal & 38 & 57 & 1.00 & & \\
\hline \multicolumn{6}{|l|}{ Parity } \\
\hline Two or less & 68 & 67 & 1.04 & $0.56-1,94$ & 0.880 \\
\hline More than two & 34 & 35 & 1.00 & & \\
\hline \multicolumn{6}{|l|}{ Level of Education } \\
\hline$<6$ years education & 65 & 67 & 0.92 & $0.50-1.70$ & 0.770 \\
\hline$\geq 6$ years education & 37 & 35 & 1.00 & & \\
\hline \multicolumn{6}{|l|}{ Occupation } \\
\hline Working outside & 41 & 39 & 1.09 & $0.79-1.38$ & 0.770 \\
\hline Housewives & 61 & 63 & 1.00 & & \\
\hline \multicolumn{6}{|l|}{ Obese parents } \\
\hline Yes & 37 & 19 & 2.49 & $1.25-4.97$ & 0.004 \\
\hline No & 65 & 83 & 1.00 & & \\
\hline
\end{tabular}


Table 2. Univariate analysis of risk factors of obesity in users of contraception (for continuous variables)

\begin{tabular}{|c|c|c|c|}
\hline Variables & $\begin{array}{c}\text { Obese } \\
\text { Mean }+\mathrm{SD}^{=}\end{array}$ & $\begin{array}{c}\text { Non obese } \\
\text { Mean }\end{array}$ & $\mathrm{p}$ \\
\hline Total duration of using contraception (months) & $66.2 \pm 57.6$ & $73.9 \pm 68.2$ & 0.390 \\
\hline Duration of using hormonal contraception (months) & $65.0 \pm 56.6$ & $48.8 \pm 37.7$ & 0.046 \\
\hline Initial weight $(\mathrm{kg})$ & $52.9 \pm 7.9$ & $45.5 \pm 6.1$ & $<0.001$ \\
\hline Height $(\mathrm{cm})$ & $151.3 \pm 5.6$ & $150.7 \pm 5.8$ & 0.600 \\
\hline Waist and hip ratio & $0.84 \pm 0.05$ & $0.81 \pm 0.5$ & $<0.001$ \\
\hline Energy expenditure (Kcal) & $1889.8 \pm 132.0$ & $1759.7 \pm 114.3$ & $<0.001$ \\
\hline Intake of energy (Kcal) & $1925.1 \pm 123.6$ & $1780.8 \pm 101.9$ & $<0.001$ \\
\hline Intake of energy (In \% RDA ${ }^{\ddagger}$ ) & $92.3 \pm 5.7$ & $93.5 \pm 4.5$ & 0.080 \\
\hline$\%$ Intake of $\mathrm{Fat}^{\S}$ & $23.6 \pm 9.5$ & $24.7 \pm 9.3$ & 0.400 \\
\hline$\%$ Intake of Carbohydrate ${ }^{\S}$ & $63.5 \pm 10.1$ & $62.0 \pm 10.4$ & 0.300 \\
\hline$\%$ Intake of Protein ${ }^{\S}$ & $12.0 \pm 3.1$ & $12.8 \pm 3.8$ & 0.120 \\
\hline
\end{tabular}

=SD, standard deviation, ${ }^{\star} \mathrm{RDA}$, recommended dietary allowance, ${ }^{\S}$ of total energy

Table 3. Types of contraception and risk of obesity

\begin{tabular}{lccccc}
\hline Contraceptive & $\begin{array}{c}\text { Obese } \\
\mathrm{n}=120\end{array}$ & $\begin{array}{c}\text { Non-obese } \\
\mathrm{n}=120\end{array}$ & $\begin{array}{c}\text { Odds } \\
\text { Ratio }\end{array}$ & $95 \% \mathrm{CI}$ & $\mathrm{p}$ \\
\hline Hormonal & & & & & \\
$\quad$ Combination Pill & $19(18,63)$ & $9(8,82)$ & 3,17 & $1.20-8.53$ & 0.009 \\
$\quad$ Injected progesterone depot & $27(26,47)$ & $16(15,69)$ & 2,53 & $1.13-5.70$ & 0.010 \\
$\quad$ Implant & $18(17,65)$ & $20(19,61)$ & 1,35 & $0.59-3.08$ & 0.440 \\
Non hormonal $^{=}$ & $38(37,25)$ & $57(55,88)$ & 1,00 & & \\
\hline
\end{tabular}

$=$ reference

Table 4 . Risk of obesity related to the duration of using hormonal contraception

\begin{tabular}{|c|c|c|c|c|}
\hline Duration & $\begin{array}{c}\text { Types } \\
\text { contraception }\end{array}$ & $\begin{array}{l}\text { Odds } \\
\text { Ratio }\end{array}$ & $95 \% \mathrm{CI}$ & $\mathrm{p}$ \\
\hline$>7$ years & $\begin{array}{l}\text { Hormonal } \\
\text { Non Hormonal }^{=}\end{array}$ & $\begin{array}{l}8.00 \\
1.00^{=}\end{array}$ & $1.33-61.73$ & 0.007 \\
\hline$>6$ years & $\begin{array}{l}\text { Hormonal } \\
\text { Non Hormonal }^{=}\end{array}$ & $\begin{array}{l}3,60 \\
1.00^{=}\end{array}$ & $0.95-14.33$ & 0.030 \\
\hline$>5$ years & $\begin{array}{l}\text { Hormonal } \\
\text { Non Hormonal }^{=}\end{array}$ & $\begin{array}{l}3,90 \\
1.00^{=}\end{array}$ & $1.20-13.22$ & 0.010 \\
\hline$>4$ years & $\begin{array}{l}\text { Hormonal } \\
\text { Non Hormonal }^{=}\end{array}$ & $\begin{array}{l}2,30 \\
1.00^{=}\end{array}$ & $0.90-5.92$ & 0.050 \\
\hline$>3$ years & $\begin{array}{l}\text { Hormonal } \\
\text { Non Hormonal }^{=}\end{array}$ & $\begin{array}{l}2,40 \\
1.00^{=}\end{array}$ & $1.09-5.23$ & 0.180 \\
\hline$>2$ years & $\begin{array}{l}\text { Hormonal } \\
\text { Non Hormonal }^{=}\end{array}$ & $\begin{array}{l}2,10 \\
1.00^{=}\end{array}$ & $1.05-4.08$ & 0.220 \\
\hline$>1$ years & $\begin{array}{l}\text { Hormonal } \\
\text { Non Hormonal }^{=}\end{array}$ & $\begin{array}{l}1,90 \\
1.00^{=}\end{array}$ & $1.01-3.57$ & 0.030 \\
\hline
\end{tabular}

$=$ reference 
Table 4. Risk of obesity related to the duration of using hormonal contraception

\begin{tabular}{|c|c|c|c|c|c|c|}
\hline Duration & $\begin{array}{l}\text { Types of } \\
\text { contraception }\end{array}$ & $\begin{array}{c}\text { Non } \\
\text { obese }\end{array}$ & Obese & $\begin{array}{l}\text { Odds } \\
\text { Ratio } \\
\end{array}$ & $95 \% \mathrm{CI}$ & $\mathrm{p}$ \\
\hline$>1$ year to 4 years & $\begin{array}{l}\text { Hormonal } \\
\text { Non Hormonal }\end{array}$ & $\begin{array}{l}17 \\
15\end{array}$ & $\begin{array}{c}33 \\
9\end{array}$ & $\begin{array}{l}2.04 \\
1.00^{=}\end{array}$ & $0.77-5.38$ & 0.150 \\
\hline$>4$ years to 7 years & $\begin{array}{l}\text { Hormonal } \\
\text { Non Hormonal }^{=}\end{array}$ & $\begin{array}{l}12 \\
12\end{array}$ & $\begin{array}{l}12 \\
10\end{array}$ & $\begin{array}{l}1.20 \\
1.00^{=}\end{array}$ & $0.38-3.83$ & 0.760 \\
\hline$>7$ years & $\begin{array}{l}\text { Hormonal } \\
\text { Non Hormonal }^{=}\end{array}$ & $\begin{array}{c}3 \\
23\end{array}$ & $\begin{array}{l}13 \\
12\end{array}$ & $\begin{array}{l}8.31 \\
1.00^{=}\end{array}$ & $1.98-34.93$ & 0.002 \\
\hline
\end{tabular}

$=$ reference

Table 4. Risk of obesity related to the duration of using hormonal contraception

\begin{tabular}{|c|c|c|c|c|c|c|}
\hline Duration & $\begin{array}{l}\text { Types of } \\
\text { contraception }\end{array}$ & $\begin{array}{l}\text { Non } \\
\text { obese }\end{array}$ & Obese & $\begin{array}{l}\text { Odds } \\
\text { Ratio }\end{array}$ & $95 \% \mathrm{CI}$ & $\mathrm{p}$ \\
\hline$>1$ year to 3 years & $\begin{array}{l}\text { Hormonal } \\
\text { Non Hormonal }^{=}\end{array}$ & $\begin{array}{r}21 \\
9\end{array}$ & $\begin{array}{r}19 \\
6\end{array}$ & $\begin{array}{l}1.36 \\
1.00^{=}\end{array}$ & $0.41-4.53$ & 0.620 \\
\hline$>3$ years to 5 years & $\begin{array}{l}\text { Hormonal } \\
\text { Non Hormonal }^{=}\end{array}$ & $\begin{array}{l}13 \\
13\end{array}$ & $\begin{array}{r}17 \\
6\end{array}$ & $\begin{array}{l}2.83 \\
1.00^{=}\end{array}$ & $0.85-9.47$ & 0.090 \\
\hline$>5$ years to 7 years & $\begin{array}{l}\text { Hormonal } \\
\text { Non Hormonal }^{=}\end{array}$ & $\begin{array}{l}5 \\
5\end{array}$ & $\begin{array}{l}9 \\
7\end{array}$ & $\begin{array}{l}1.29 \\
1.00=\end{array}$ & $0.26-6.27$ & 1.000 \\
\hline$>7$ years & $\begin{array}{l}\text { Hormonal } \\
\text { Non Hormonal }^{=}\end{array}$ & $\begin{array}{r}3 \\
23 \\
\end{array}$ & $\begin{array}{l}13 \\
12\end{array}$ & $\begin{array}{l}8.31 \\
1.00=\end{array}$ & $1.98-34.93$ & 0.002 \\
\hline
\end{tabular}

$=$ reference

Table 5. Odds ratio of obesity in users of contraception ${ }^{=}$

\begin{tabular}{|c|c|c|c|}
\hline Covariates & $\begin{array}{c}\text { Multivariate } \\
\text { Odds Ratio }\end{array}$ & $95 \% \mathrm{CI}$ & $\mathrm{p}$ \\
\hline \multicolumn{4}{|l|}{ Types of contraception used } \\
\hline Hormonal & 9.40 & $1.09-81.5$ & 0.040 \\
\hline Non hormonal & 1.00 (reference) & & \\
\hline Duration of using hormonal & 1.03 & $1.002-1.06$ & 0.040 \\
\hline Contraception (month) & 1.00 (reference) & & \\
\hline \multicolumn{4}{|l|}{ Obese parents } \\
\hline No & 1.00 & $0.002-0.64$ & 0.020 \\
\hline Yes & 25.00 (reference) & & \\
\hline
\end{tabular}

Table 6. Food intake and energy expenditure of hormonal and non-hormonal contraceptive users

\begin{tabular}{lccc}
\hline Variables & $\begin{array}{c}\text { Hormonal } \\
\text { Mean } \pm \mathrm{SD}^{=}\end{array}$ & $\begin{array}{c}\text { Hormonal } \\
\text { Mean } \pm \mathrm{SD}^{=}\end{array}$ & $\mathrm{p}$ \\
\hline Energy (Kcal) & $1871.9 \pm 140.3$ & 1831.2124 .0 & 0.030 \\
Energy (in \% RDA $^{\ddagger}$ ) & $92.5 \pm 5.47$ & 93.34 .9 & 0.290 \\
\% Intake of Fat & $23.4 \pm 9.0$ & 25.19 .9 & 0.180 \\
\% Intake of Carbohydrate & $63.8 \pm 9.3$ & 61.411 .2 & 0.100 \\
\% Intake of Protein & $12.3 \pm 3.6$ & 12.53 .6 & 0.730 \\
Energy expenditure (Kcal) $^{\S}$ & $1843.7 \pm 148.9$ & 1803.0124 .7 & 0.040 \\
\hline
\end{tabular}

= SD, standard deviation, ${ }^{\ddagger}$ RDA, recommended dietary allowance, ${ }^{\S}$ of total energy 


\section{DISCUSSION}

Our data shows that users of hormonal contraception, face over all about 9 times risk of obesity compared to users of non-hormonal contraception. The risk is highest when the method of contraception has been used for more than seven years. Kasseru in 1994 reported that injected depot medroxyprogesterone acetat increased weight approximately $2 \mathrm{~kg}$ in the first year, while kaushik in 1998 reported a weight gain of 4-6 pounds in the first year. ${ }^{5,7,13,14}$ Cushman et al (1996), also reported that more than $50 \%$ of hormonal contraceptive users believed that injected DepoProvera led to weight gain. ${ }^{15}$

Our study also showed increased risk of obesity in users of injected progesterone depot, OR: 2.53 (95\% CI: 1.1-5.7), but the risk is higher in users of combination pills, OR: 3.17 (95\% CI: 1.2-8.5).

Duration in utilization of hormonal contraception is related to higher risk of obesity. Our data showed a steadily increasing risk of obesity the longer the contraception is used. After seven years of using hormonal contraception the risk of obesity is 8.3 folds higher intramuscularly injected depot of progesterone or subcutaneous implantation of low-dose levonorgestrel or etonorgestrel (implant). Longer use of hormonal contraception related to higher risk of obesity. The risk is also higher in offsprings of obese parents.

\section{Recommendations}

Offspring of obese parents should be advised to avoi using hormonal contraception, especially combination pills and injected progesterone depot. To avoid obesity, after seven years, continuous utilization of hormonal contraception should be reconsidered.

\section{Acknowledgements}

I would like to thank the Head of the National Family Planning Coordination Board (BKKBN) who had given financial support, and to Faculty Member of the Gadjah Mada University for giving me the chance to complete this study.

\section{REFERENCES}

1. Wilopo SA. Dinamika penurunan fertilitas dan implikasinya pada kebijaksanaan program KB di Indonesia. Berita Kedokteran Masyarakat X (3) 1994 : 130-2.

2. Kantor Menteri Negara Kependudukan / BKKBN. Undangundang Nomor 10 Tahun 1992 Tentang Perkembangan Kependudukan dan Pembangunan Keluarga Sejahtera Jakarta. Kantor Menteri Kependudukan. 1995. BKKBN.

3. Affandi B. Pekerja Wanita dan Keluarga Berencana. MKD vol.9, No.10/November $1990: 1990,50-2$.

4. Syaban. Rapid Survey. Pemilihan dan penggunaan alat kontrasepsi rasional di kodya Semarang, November 1991. Majalah Kesehatan Masyarakat Indonesia. Tahun XX Nomor 9, $1992:$ 538-41.

5. BPS. Survei Demografi dan Kesehatan Indonesia 1997. Biro Pusat Statistik Jakarta, Indonesia, 1998.

6. BKKBN. Umpan balik laporan. BKKBN. Kabupaten Kulon Progo Jogjakarta. 2001.

7. Siswosudarmo HR, Anwar HM, Emilia O. Teknologi Kontrasepsi. Gadjah Mada University Press, Jogjakarta, 2001.

8. Daphne. Drug induced nutritional deficiencies. Cornell University Ithaca. New York. 1983.

9. Katcher BS. Young Iy. Koda-Kimble MA. Applied Therapeutics. The Clinical use of Drugs. Applied Therapeutics, Inc. Spokane, 1987.

10. Sukaton. Kelainan Metabolik pada Obesitas. MKD Vol 9 No. 10 November 1990.

11. Centers for Disease Control. Epiinfo 2000 version 1.0. Atlanta Ga, 2000.

12. Stata Corporation, Intercooled Stata 6,0. USA. University Drive East, 1999.

13. Kesseru E. Aydinlik S. Etchepareborda JJ. Multicentred, phase III clinical trial of norethisterone enanthate $50 \mathrm{mg}$ plus estradiol valerate $5 \mathrm{mg}$ as a monthly injectable contraceptive: final three-year report. Contraception. 1994; 50:329-37.

14. Kaushik N. Depo Provera and Weight Gain. Noteworthy Nutrition papers. Vol.1. No. 1, 1998.

15. Chusman LF, Kalmuss D, Davidson AR, Heartwell S, Rulin M. Belief about Depo-Provera among three groups of contraceptors. Advances in contraception 1996; 12: 43-52. 
